\title{
PENGARUH SUBJECT SPECIFIC PEDAGOGY TEMATIK TERHADAP \\ KARAKTER HORMAT DAN TANGGUNG JAWAB \\ PADA SISWA KELAS III SEKOLAH DASAR
}

\author{
Junaidi dan Zuhdan Kun Prasetyo \\ Program Pascasarjana Universitas Negeri Yogyakarta \\ email: j.edy69@yahoo.com
}

\begin{abstract}
A bstrak: Penelitian ini bertujuan mendeskripsikan pengaruh Subject Specific Pedagogy (SSP) tematik dalam pembelajaran terhadap karakter sikap hormat dan tanggung jawab siswa. Penelitian merupakan penelitian eksperimen semu dengan nonequival ent groups pretest-posttest design. Populasi penelitian ini adalah seluruh siswa kelas III di SDN 007 Pangkalan Kerinci Kabupaten Pelalawan tahun ajaran 2013/ 2014. Sampel dipilih dengan teknik simple random sampling. Dari lima rombongan belajar dipilih secara acak sehingga didapat tiga kelas sebagai sampel penelitian. Pengumpulan data dengan teknik observasi dan wawancara. Teknik analisis data yang digunakan adalah uji perpasangan (paired t- tes) dan uji beda Independen T- tes dengan taraf signifikansi $5 \%$ atau 0,05 . Hasil penelitian ini adalah SSP tematik secara signifikan berpengaruh positif terhadap karakter sikap hormat siswa dibandingkan dengan pembelajaran tematik yang tidak menggunakan SSP tematik diperoleh sig < a yaitu sig=0,000 < $\mathrm{a}=0,05$ dengan $\mathrm{t}=10,519$; dan karakter tanggung jawab siswa dibandingkan dengan pembelajaran tematik diperoleh sig $<\alpha$ yaitu sig $=0,000<\alpha=0,05$ dengan $t=8,442$.
\end{abstract}

Kata Kunci: subject specific pedagogy tematik, sikap hormat, tanggung jaw ab

\section{THE EFFECT OF THEMATIC SUBJECT SPECIFIC PEDAGOGY ON THE CHARACTER OF RESPECT AND RESPONSIBILITY OF GRADE III PRIMARY SCHOOL STUDENTS}

\begin{abstract}
A bstract: This study aimed at describing the influence of thematic Subject Specific P edagogy (SSP) learning on the students' character of respect and responsibility. The research was a quasi-experimental study with pretest-posttest nonequivalent groups design. The population of the study was the whole third grade students at SDN 007 Pangkalan Kerinci, Pelalawan in the academic year 2013/ 2014. The sample was selected by a simple random sampling technique. A sample of three classes were selected randomly from the five study groups available. Data collection was done by observation and interview techniques. Data analysis technique used was pairing test (paired t-test) and the Independent different test T-test with a significance level of $5 \%$ or 0.05 . The results of this study showed that thematic SSP learning had a significantly better effect on the character of respect compared with thematic learning of the students who did not use thematic SSP, with a significnace value sig $<\mathrm{a}$ ie $\operatorname{sig}=0,000$ $<\alpha=0.05 t=10.519$; and had significantly better character of responsibility compared with those without using thematic SSP with a significance value sig $<\alpha$ ie sig $=0,000<\alpha=0.05 t=8.442$.
\end{abstract}

Keyw ords: subject-specific pedagogy thematic, respect, responsibility

\section{PENDAHULUAN}

Pendidikan pada hakikatnya adalah upaya sadar dari suatu masyarakat dan pemerintah suatu negara untuk menjamin kelangsungan hidup dan kehidupan generasi penerus, agar mampu mengantisipasi hari depan yang senantiasa berubah. Dalam kegiatan mendidik, manusia selalu memiliki perbedaan sudut pandang, perbedaan kon- sepsi tentang pendidikan sehingga penentuan tujuan pendidikan menjadi sesuatu yang penting. Pemerintah telah menyusun programpendidikan karakter, dalam rangka meningkatkan sumber daya manusia. Pendidikan karakter merupakan nilai-nilai perilaku manusia yang berhubungan dengan Tuhan Yang Maha Esa, diri sendiri, sesama manusia, lingkungan, dan kebang- 
saan yang terwujud dalam pikiran, sikap, perasaan, perkataan, dan perbuatan berdasarkan norma-norma agama, hukum, tata krama, budaya, dan adat istiadat.

Pendidikan karakter seharusnya dapat membawa peserta didik ke pengenalan nilai secara kognitif, penghayatan nilai secara afektif, dan akhirnya ke pengamalan nilai secara nyata. Lickona (1991:53-62) menekankan pentingnya tiga komponen karakter yang baik (component of good character) dalam mengembangkan pendidikan karakter, yaitu: moral knowing atau pengetahuan tentang moral, moral feeling atau perasaan tentang moral, dan moral action atau perbuatan bermoral. Dengan memadukan secara seimbang ketiga komponen tersebut, peserta didik akan mampu menghayati dan memahami nilai-nilai luhur yang khasbaik (tahu nilai kebaikan, mau berbuat baik nyata berkehidupan baik, dan berdampak baik terhadap lingkungan. Dengan ketiga komponen tersebut pendidikan karakter senantiasa mengarahkan diri pada pembentukan individu bermoral, cakap mengambil keputusan yang tampil dalam perilakunya, sekaligus mampu berperan aktif dalam membangun kehidupan bersama dalam tantangan global.

Pembelajaran seharusnya dilaksanakan dengan mengembangkan tiga ranah kognitif, afektif, dan psikomotor secara komprehensif. Pemerintah sudah berupaya mengatasi masalah tersebut dengan mengeluarkan Peraturan Pemerintah Nomor 19 Tahun 2005 tentang Standar Nasional Pendidikan (SNP). SNP di dalamnya terdapat standar isi yang kemudian dikembangkan oleh Badan Standar Nasional Pendidikan (BSNP) dan ditetapkan dengan Permendiknas No. 22 Tahun 2006 tentang Standar Isi untuk Satuan Pendidikan Dasar dan Menengah mengisyaratkan agar guru memiliki Subject Specific Pedagogy (SSP).
SSP merupakan pengemasan materi menjadi perangkat pembelajaran yang komprehensif dan mendidik, dapat membentuk peserta didik yang berkarakter dengan nilai-nilai norma yang berlaku. Proses menciptakan peserta didik yang sesuai dengan norma-norma yang berlaku, masih terdapat kendala dalam pelaksanaan pembelajaran, baik karena faktor guru maupun sarana pendukung lainnya. Bagi para guru, beban untuk memenuhi kompetensi inti dan kompetensi dasar bagi peserta didik dengan jumlah jam pelajaran yang terbatas mendorong guru untuk lebih banyak menanamkan konsep pengetahuan daripada memenuhi kebutuhan belajar yang holistik, apalagi jika di dalamnya terintegrasi dengan pendidikan karakter.

Berdasarkan hasil prasurvei yang telah dilaksanakan pada bulan Januari 2014, terlihat bahwa proses pembelajaran siswa di kelas 3 (tiga) Sekolah Dasar Negeri 007 Pangkalan Kerinci pelaksanaan pendidikan karakter di sekolah masih banyak terdapat kelemahan-kelemahan dalam pembelajaran, selama ini hanya menekan pada ranah kognitif atau pengetahuan dan belum kepada sikap perilaku siswa, sehingga terdapat perilaku siswa yang menyimpang, di antaranya kurang hormat dan kurang bertanggung jawab pada diri sendiri maupun kepada orang lain, baik dalam proses belajar maupun di luar proses belajar. Selain itu, perangkat pembelajaran yang digunakan masih bersifat penekanan pada tingkat pengetahuan siswa. Banyaknya realita permasalahan yang terjadi, diperlukan suatu usaha untuk menghilangkan budaya dan sikap siswa tersebut. Hal ini sangat berkaitan dengan kemampuan seorang tenaga pengajar untuk membentuk sikap yang lebih baik terhadap siswa dengan suatu teknik yang baik, yakni dengan menggunakan perangkat pembelajaran yang mendi- 
dik berupa SSP tematik. California State U niversity N orthridge (2006: 5) menjelaskan bahwa "Subject specific pedagogy, also known as pedagogical content knowledge, is a form of teacher knowledge and a part of a teacher's thinking process". Oleh karena itu, pengetahuan ini berusaha menjembatani antara pencapaian pengetahuan mata pelajaran dengan perubahan lingkungan dalam pembelajaran, sehingga mengembangkan nilai karakter peserta didik secara bertahap. SSP tematik yang terintegrasi pendidikan karakter bertujuan untuk membangun seluruh dimensi manusia dengan pendekatan ilmiah (scientific approach) pada pengalaman belajar yang menyenangkan dan inspiratif untuk peserta didik. Karena pembelajaran tematik adalah pembelajaran yang menggunakan tema dalam mengaitkan be berapa mata pembelajaran yang menolak proses latihan atau hapalan (drill) sebagai dasar pembentukan pengetahuan dan struktur intelektual anak. Teori pembelajaran ini dimotori para tokoh Psikologi Gestalt, yang menekankan bahwa pembelajaran itu haruslah bermakna dan berorientasi pada kebutuhan dan perkembangan anak. Pendekatan pembelajaran tematik lebih menekankan pada penerapan konsep belajar sambil melakukan sesuatu (learning by doing), sehingga membentuk sikap hormat dan tanggung jawab siswa serta nilai-nilai karakter yang mulia pada peserta didik.

Merujuk pada hasil observasi dan wawancara pada beberapa sekolah dasar di Kecamatan Pangkalan Kerinci Kabupaten Pelalawan yang dilakukan saat prasurvei bulan Januari 2014 tersebut, untuk pembelajaran tematik saat ini nilai afektif peserta didik belum memuaskan. Aspek sikap hormat, tanggung jawab, sikap objektif, berpikir kritis, peserta didik cenderung pasif.
Berdasarkan latar belakang yang telah diuraikan, penulis berusaha melihat dan mengukur sampai menganalisis pengaruh SSP tematik tehadap karakter sikap hormat dan tanggung jawab pada siswa kelas III sekolah dasar di SDN 007 PangkaIan Kerinci. Karakter atau nilai-nilai yang seharusnya diajarkan di sekolah, seperti yang dikemukkan Lickona (1991:45), "Respect and responsibility are two foundational moral values that schools should teach. There are such as honesty, fairness, tolerance, prudence, self-discipline, helpfulness, compassion, cooperation, courage, and a host of democratic values are from of respect and/or responsibility or aids to acting respectfully and responsibility". Sikap hormat dan bertanggung jawab adalah dua nilai moral dasar yang harus diajarkan di sekolah. Beberapa nilai yang lain seperti nilai kejujuran, keadilan, toleransi, kebijaksanaan, disiplin diri, tolong menolong, peduli sesama, kerja sama, keberanian, dan sikap demokratis merupakan bentuk dari rasa hormat dan tanggung jawab ataupun sebagai media pendukung untuk bersikap hormat dan bertanggung jawab.

Definisi sikap hormat dikemukakan oleh Lickona (1991:43), "R espect means showing regard for the worth someone or some thing. It takes three major froms: respect for oneself, respect for other people, and respect for all from of life and the environment that sustains them". Maksudnya, rasa hormat berarti menunjukkan penghargaan terhadap seseorang atau sesuatu. Terdapat tiga hal yang menjadi pokok, yaitu penghormatan terhadap diri sendiri, penghormatan terhadap orang lain, dan penghormatan terhadap semua bentuk kehidupan dan lingkungan yang saling menjaga satu sama lain.

Penghormatan terhadap diri sendiri, mengharuskan untuk memperlakukan apa yang ada pada kehidupan sebagai manusia yang memiliki nilai secara alami. Meskipun 
demikian, perlakuan yang mengarah kepada perusakan diri seperti perkelahian dan penyalahgunaan narkoba merupakan jalan yang salah. Penghormatan terhadap orang lain, mengharuskan seseorang untuk memperlakukan semua orang bahkan orangorang yang bencinya sebagai manusia yang memiliki nilai tinggi dan memilki hak yang sama sebagai individu. Penghormatan kepada semua bentuk kehidupan dan lingkungan, dapat dijelaskan bahwa tindakan kasar yang dilakukan terhadap hewan juga menjadi sesuatu yang dilarang sehingga diharuskan untuk berlaku baik dengan cara melindungi alam dan lingkungan.

Peserta didik dapat mewujudkan sikap hormat yang terlihat pada: (1) bersikap sopan dan santun; (2) menghormati aturan; dan (3) menghargai perbedaan. Sopan dan santun akan ditunjukan dengan perbuatan atau perilaku sesuai dengan tataran norma dan adat istiadat setempat, sopan dapat terlihat pada tingkah-laku seperti menggunakan pakaian yang baik dan menutup aurat, cara berjalan di depan orang yang lebih dewasa dengan menundukkan kepala, serta santun dapat diwujudkan dalam berbicara atau menggunakan bahasa yang baik seperti mengucapkan terima kasih, maaf, tolong, pujian, dan memberikan dorongan/motivasi kepada peserta didik yang lain dan kepada guru. Menghormati aturan adalah taat pada peraturan yang berlaku baik di lingkungan keluarga, sekolah, maupun di masyarakat, misalnya menaati dan menjalan aturan dalam proses belajar mengajar. Sementara itu, dalam hal mengahargai perbedaan, peserta didik diupayakan untuk menanamkan kerja sama, dan peserta didik menyadiri tentang kedudukannya, baik di kelas maupun di luar kelas, misalnya kedudukannya sebagai siswa harus hormat terhadap guru dan kepala sekolah.
Tanggung jawab bukan sifat yang dibawa sejak lahir atau diwarisi dari orang tua. Tanggung jawab harus dipelajari melalui pengalaman. Tanggung jawab secara harfiah berarti "kemampuan untuk merespons atau menjawab" berarti berorientasi terhadap orang lain, memperhatikan mere ka, secara aktif menanggapi kebutuhan mereka. Tanggung jawab menekankan kewajiban positif kita untuk peduli satu sama lain. Clemes dan Bean (2001: 2-3), menyatakan bahwa tanggung jawab adalah kemampuan untuk menanggapi. Selanjutnya Rich (2008:66) menyatakan, "Teaching children to be responsible involves finding ways to help children feel competent, to know what's right and to do what's right". Secara umum tanggung jawab juga berarti mengambil keputusan yang patut dan efektif. Karakter tanggung jawab yang dimaksud dalam penelitian ini adalah sikap hidup yang melaksanakan tugas dan kewajiban secara sungguh-sungguh dengan sebaik mungkin, sesuai peranannya sebagai makhluk individu maupun makhluk sosial di masyarakat dan siap menerima konsekuensi terhadap perbuatan yang telah dilakukan. Karakter tanggung jawab yang akan diamati adalah tanggung jawab siswa di kelas, melaksanakan tugas yang diberikan guru dengan sebaik-baiknya, menjaga kebersihan kelas, mengembalikan buku dan alat pembelajaran yang telah dipinjam dari guru. Tanggung jawab di lingkungan sekolah, misalnya menjaga kebersihan sekolah de ngan membuang sampah pada tempatnya. Hal lain yang diamati adalah siap menerima konsekuesi terhadap perbuatan yang dilakukan seperti mengganti buku yang hilang akibat dari kelalaiannya.

\section{METODE}

Penelitian ini menggunakan pendekatan kuantitatif dengan metode quasi-ex- 
periment atau eksperimen semu yang membandingkan dua perlakuan yang berbeda kepada subjek penelitian. Penelitian ini bertujuan mengetahui pengaruh SSP tematik terhadap karakter peserta didik.

Penelitian ini menggunakan desain nonequivalent groups pretest-posttest control group design. McMilan \& Schumacher (2010: 278) mengemukakan, " $N$ on equival ent groups pretest-posttest control or comparison group designs are designs very prevalent and useful in education, because it is often impossible to randomly assign subject". Gambar visual desain penelitian ini adalah seperti tampak pada Gambar 1.

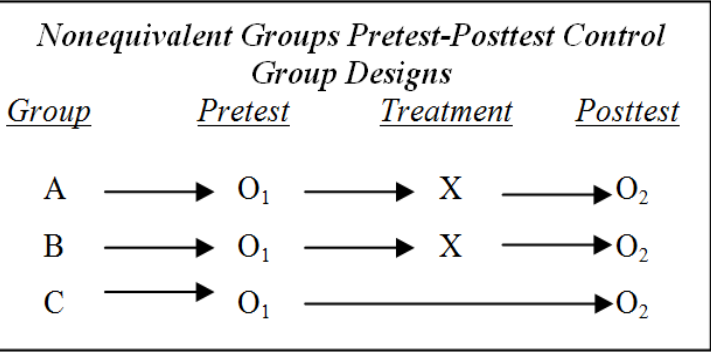

\section{Gambar 1. Desain Penelitian Nonequivalent G roups Pretest-Posttest Design}

Keterangan:

$\mathrm{A}=$ Kelompok Eksperimen

B $=$ Kelompok Eksperimen

$\mathrm{C}=$ Kelompok Kontrol

$\mathrm{O}_{1}=$ Pretest pada kelompok eksperimen dan kelompok kontrol

$\mathrm{O}_{2}=$ Posttest pada kelompok eksperimen dan kelompok kontrol

$X=$ Perlakuan dengan menggunakan Subject Specific Pedagogy tematik.

Populasi pada penelitian ini adalah peserta didik kelas III SDN 007 Pangkalan Kerinci yang berjumlah 194 peserta didik yang terbagi dalam 5 rombongan belajar (rombel) Tahun Pelajaran 2013/ 2014. Sampel diambil dengan cara teknik Simple Random Sampling. Kelima rombongan belajar tersebut memiliki peluang yang sama untuk terpilih sebagai kelas sampel dengan dipilih secara acak sehingga ditetapkan $\mathrm{Ke}$ las $3 A$ sebagai $K E 1$, Kelas $3 C$ sebagai KE2, dan Kelas 3D sebagai kelas kontrol.

Teknik pengumpulan data yang digunakan adalah teknik nontes, yaitu observasi dan wawancara. Observasi dilakukan untuk memperoleh data tentang karakter sikap hormat dan tanggung jawab peserta didik. Lembar observasi yang berisi 43 butir pernyataan, baik pernyataan positif maupun negatif yang terbagi ke dalam dua kategori nilai yaitu, sikap hormat dan tanggung jawab. Untuk karakter sikap hormat terdiri dari 25 butir pernyataan dan 18 butir untuk karakter tanggung jawab dengan pilihan jawaban menggunakan skala rentang (rating-scale) yang dibuat dalam bentuk checklist dengan skor yang diberikan 14. Wawancara dilakukan kepada sebagian peserta didik saja karena hanya untuk memperoleh data pendukung terhadap nilai karakter peserta didik yang tidak dapat diamati pada saat observasi. Pedoman wawancara terdiri 25 butir pernyataan yang terbagi ke dalam dua kategori nilai, yaitu sikap hormat dan tanggung jawab. Karakter sikap hormat terdiri dari 14 butir pernyataan dan 11 butir untuk karakter tanggung jawab.

Teknik analisis data yang digunakan adalah teknik statistik deskriptif. Langkah yang dilakukan pada tahap deskripsi data ini adalah membuat rangkuman distribusi data pretest dan posttest dari hasil statistik deskriptif program SPSS V ersion 20.0 for Windows. Untuk menguji hipotesis dilakukan mencari dalam pengaruh signifikan dengan menggunakan uji perpasangan (paired t- tes) dan uji perbedaan antara kelompok perlakuan dan kelompok kontrol dengan menggunakan uji beda Independen T-tes, yaitu dengan menggunakan program software 
SPSS V ersion 20.0 for W indows dengan taraf signifikansi $5 \%$ atau 0,05.

\section{HASIL DAN PEMBAHASAN}

Hasil penelitian dengan menggunakan SSP tematik yaitu berupa hasil observasi karakter peserta didik. Data penelitian ini meliputi data penilaian nilai karakter yang terdiri dari data pretest dan post-test yang diperoleh melalui lembar observasi karakter peserta didik. Secara singkat dapat dideskripsikan data nilai karakter yang mengungkapkan informasi nilai minimum, maksimum, jumlah, rata-rata, standar deviasi dan varians pada masing-masing kelas eksperimen 1, kelas eksperimen 2, dan kelas kontrol. Data tersebut digunakan untuk menganalisis normalitas, homogenitas, dan uji-t perbedaan maupun uji t pengaruh sehingga dapat diketahui bagaimana perbandingan hasil pengamatan karakter sikap hormat dan tanggung jawab pada kelompok yang diberikan treatment melalui penerapan SSP tematik dalam proses pembelajaran keseluruhan (eksperimen) dan yang tidak diberikan treatment (kontrol). Selain itu, data juga disajikan dalam bentuk histogram dan distribusi frekuensi.

\section{Observasi Sikap Hormat pada $K_{1}$ dan $\mathrm{KE}_{2}$}

Hasil analisis deskriptif penelitian tentang hasil observasi sikap hormat pada kelas eksperimen 1 dan pada kelas eksperimen 2 dapat dilihat pada Tabel 1 .

Tabel 1. Hasil Observasi Sikap Hormat pada $K E_{1}$ dan $K E_{2}$

\begin{tabular}{rrcccc}
\hline $\begin{array}{c}\text { Obser } \\
\text { vasi }\end{array}$ & $\begin{array}{c}\text { mini } \\
\text { mum }\end{array}$ & $\begin{array}{c}\text { maxi } \\
\text { mum }\end{array}$ & $\begin{array}{c}\text { rata- } \\
\text { rata }\end{array}$ & $\begin{array}{c}\text { Standar } \\
\text { Deviasi }\end{array}$ \\
\hline KE1 & A wal & 54,0 & 60,0 & 56,20 & 1,68655 \\
& A khir & 60,0 & 65,0 & 61,80 & 1,81353 \\
KE2 & A wal & 50,0 & 56,0 & 53,78 & 2,10819 \\
& A khir & 56,0 & 64,0 & 60,44 & 2,50555 \\
\hline
\end{tabular}

Tabel 1 menunjukkan perolehan hasil observasi awal sikap hormat pada kelas eksperimen 1 , yaitu terendah 54,00 , tertinggi adalah 60,00 , rata-rata 56,20 dengan standar deviasi sebesar 1,68655, sedangkan hasil observasi akhir terendah 60,00 , tertinggi 65,00 , rata-rata 61,80 dengan standar deviasi sebesar 1,81353. Hasil observasi awal sikap hormat pada kelas eksperimen 2 terendah 50,00, tertinggi 56,00 , rata-rata 53,78 dengan standar deviasi sebesar 2,10819, sedangkan hasil observasi akhir terendah 56,00 , tertinggi 64,00 , rata-rata 60,44 dengan standar deviasi sebesar 2,50555.

Berdasarkan hasil observasi di atas, untuk mengetahui perubahan sikap hormat peserta didik adalah membanding hasil rata-rata observasi awal dengan hasil ratarata observasi akhir pada setiap kelas eksperimen. Hasil rata-rata observasil awal sikap hormat pada kelas eksperimen 1 yaitu sebesar 56,20 dan mengalami peningkatan pada observasi akhir dengan hasil rata-rata 61,80 . Hasil rata-rata observasi awal sikap hormat pada kelas eksperimen 2 sebesar 53,78dan mengalami peningkatan pada observasi akhir dengan hasil rata-rata 60,44. Untuk lebih jelasnya mengenai hasil tersebut dapat dilihat pada Gambar 2.

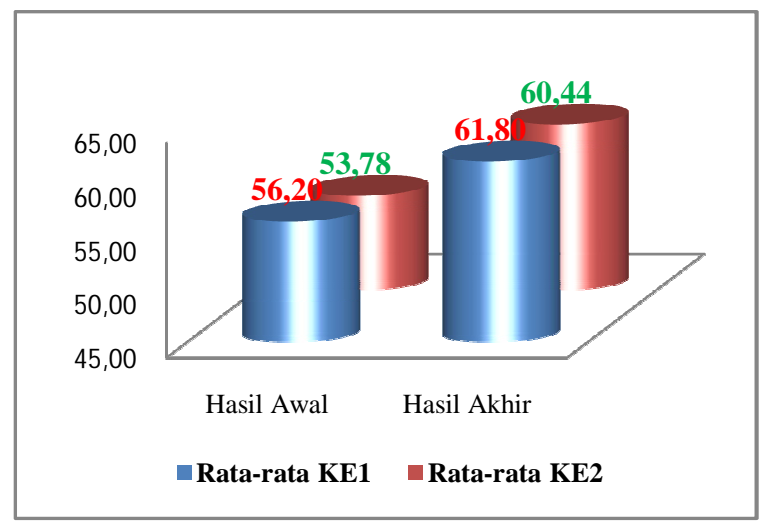

G ambar 2. H istogram Hasil O bservasi Awal dan Observasi A khir Sikap Hormat pada Kelas Eksperimen 1 dan 2 
O bservasi Tanggung Jawab pada $\mathrm{KE}_{1}$ dan $\mathrm{KE}_{2}$

Hasil analisis deskriptif penelitian tentang hasil observasi tanggung jawab pada kelas eksperimen 1 dan pada kelas eksperimen 2 dapat dilihat pada Tabel 2 .

Tabel 2. Hasil O bservasi Tanggung Jawab pada $K_{1} E_{1}$ dan $K_{2}$

\begin{tabular}{cccccc}
\hline & $\begin{array}{c}\text { Obser } \\
\text { vasi }\end{array}$ & $\begin{array}{c}\text { mini } \\
\text { mum }\end{array}$ & $\begin{array}{c}\text { maxi } \\
\text { mum }\end{array}$ & $\begin{array}{c}\text { rata- } \\
\text { rata }\end{array}$ & $\begin{array}{c}\text { Standar } \\
\text { Deviasi }\end{array}$ \\
\hline KE1 & Awal & 44,0 & 53,0 & 47,00 & 2,53859 \\
& Akhir & 49,0 & 56,0 & 51,90 & 1,91195 \\
KE2 & Awal & 39,0 & 52,0 & 46,78 & 3,76755 \\
& A khir & 45,0 & 55,0 & 51,22 & 3,15348 \\
\hline
\end{tabular}

Tabel di atas menunjukkan perolehan hasil observasi awal tanggung jawab pada kelas eksperimen 1 , yaitu terendah 44,00 , tertinggi 53,00 , rata-rata 47,00 dengan standar deviasi sebesar 2,53859, sedangkan hasil observasi akhir yaitu terendah 49,00, tertinggi 56,00 , rata-rata 51,90 dengan standar deviasi sebesar 1,91195. Hasil observasi awal tanggung jawab pada kelas eksperimen 2 yaitu terendah 39,00 , tertinggi 52,00 , hasil rata-rata 46,78 dengan standar deviasi se besar 3,76755, sedangkan hasil observasi akhir yaitu terendah 45,00, tertinggi 55,00 , rata-rata 51,22 dengan standar deviasi se besar 3,15348.

Berdasarkan hasil observasi di atas, untuk mengetahui perubahan tanggung jawab peserta didik adalah membanding hasil rata-rata observasi awal dengan hasil rata-rata observasi akhir pada setiap kelas eksperimen. Hasil rata-rata observasi awal karakter tanggung jawab pada kelas eksperimen 1 sebesar 47,00 dan mengalami peningkatan pada observasi akhir dengan hasil rata-rata 51,90. Pada kelas eksperimen 2 sebesar 46,78 dan mengalami peningkatan pada observasi akhir dengan hasil rata-rata
51,22 . Hasil yang lebih jelas dapat dilihat pada Gambar 3.

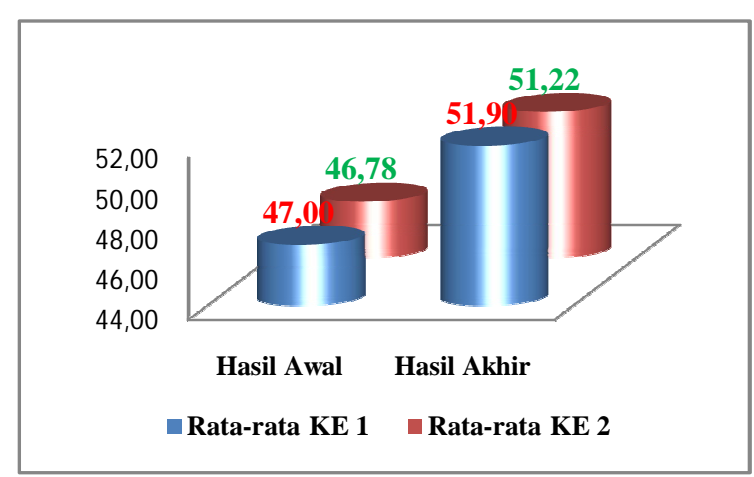

\section{G ambar 3. Histogram Hasil O bservasi A wal dan O bservasi A khir Tanggung Jawab pada KE 1 dan 2}

\section{O bservasi Sikap Hormat pada Kelas Kon- trol}

Hasil analisis deskriptif penelitian tentang hasil observasi sikap hormat pada kelas kontrol dapat dilihat pada Tabel 3.

\section{Tabel 3. Hasil Observasi Sikap Hormat pada Kelas kontrol}

\begin{tabular}{ccccc}
\hline $\begin{array}{c}\text { Obser } \\
\text { vasi }\end{array}$ & minimum maximum & $\begin{array}{c}\text { rata- } \\
\text { rata }\end{array}$ & $\begin{array}{c}\text { Standar } \\
\text { Deviasi }\end{array}$ \\
\hline Awal & 38,00 & 54,00 & 47,30 & 4,47338 \\
Akhir & 40,00 & 53,00 & 47,60 & 3,86437 \\
\hline \multicolumn{4}{c}{ Pada Tabel 3 terlihat hasil } & observasi
\end{tabular}
awal sikap hormat pada kelas kontrol, yaitu terendah 38,00, tertinggi 54,00, rata-rata 47,30 dengan standar deviasi 4,47338, sedangkan hasil observasi akhir terendah 40,00 , tertinggi 53,00 , hasil rata-rata 47,60 dengan standar deviasi sebesar 3,86437.

Berdasarkan hasil observasi di atas, untuk mengetahui perubahan sikap hormat peserta didik adalah membanding hasil rata-rata observasi awal dengan hasil ratarataobservasi akhir pada kelas kontrol. Hasil rata-rata observasi awal sikap hormat pada siswa kontrol yaitu sebesar 47,30 dan hanya mengalami peningkatan pada observasi akhir sebesar 47,60. Untuk lebih jelas dapat dilihat pada Gambar 4. 


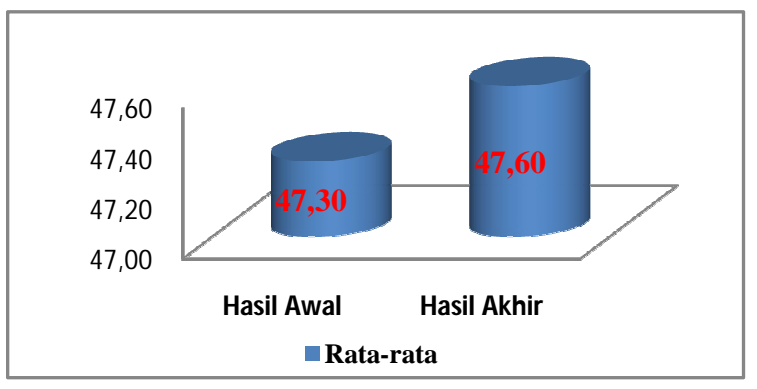

G ambar 4. Histogram $\mathrm{H}$ asil O $\mathrm{O}$ bservasi A wal dan 0 bservasi A khir Sikap H ormat pada Kelas Kontrol

\section{Observasi Tanggung Jawab pada Kelas Kontrol}

Hasil analisis deskriptif penelitian tentang hasil observasi tanggung jawab pada kelas kontrol dapat dilihat pada Tabel 4.

Tabel 4. Hasil O bservasi Tanggung Jawab pada Kelas kontrol

\begin{tabular}{ccccc}
\hline $\begin{array}{c}\text { Obser } \\
\text { vasi }\end{array}$ & $\begin{array}{c}\text { minimu } \\
\mathrm{m}\end{array}$ & $\begin{array}{c}\text { maximu } \\
\mathrm{m}\end{array}$ & $\begin{array}{c}\text { rata- } \\
\text { rata }\end{array}$ & $\begin{array}{c}\text { Standar } \\
\text { Deviasi }\end{array}$ \\
\hline A wal & 37,00 & 47,00 & 42,50 & 3,24037 \\
Akhir & 39,00 & 47,00 & 43,10 & 2,68535 \\
\hline
\end{tabular}

Pada Tabel 4 terlihat hasil observasi awal tanggung jawab pada kelas kontrol, yaitu terendah 37,00 , tertinggi 47,00 , ratarata 42,50 dengan standar deviasi sebesar 3,24037, sedangkan hasil observasi akhir yaitu terendah 39,00 , tertinggi 47,00 , ratarata 43,10 dengan standar deviasi sebesar 2,68535 .

Berdasarkan hasil observasi di atas, untuk mengetahui perubahan sikap hormat peserta didik adalah membanding hasil rata-rata observasi awal dengan hasil ratarata observasi akhir pada kelas kontrol. Hasil rata-rata observasi awal karakter tanggung jawab pada kelas kontrol yaitu 42,50 dan hanya mengalami peningkatan pada observasi akhir sebesar 43,10. Untuk lebih jelasnya tentang hasil tersebut dapat dilihat pada Gambar 5.

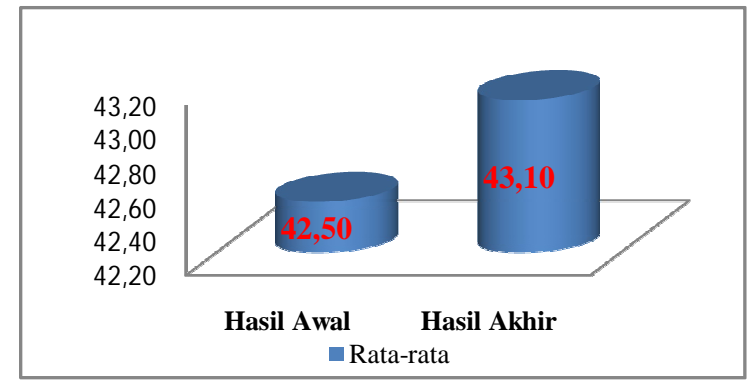

\section{Gambar 5. H istogram Hasil O bservasi A wal dan 0 bservasi Akhir Tanggung Jawab pada Kelas kontrol}

Berdasarkan analisis deskriptif dan pengujian hipotesis diketahui adanya perbedaan nilai karakter sikap hormat dan tanggung jawab antara kelas eksperimen satu $\left(K_{1}\right)$, eksperimen dua $\left(K_{2}\right)$, dan kelas kontrol $(K K)$ yang signifikan. Hal tersebut ditunjukkan dengan hasil yang dilakukan dengan menggunakan analisis uji t-tes sampel berpasangan (paired t-tes) untuk menguji pengaruh. Untuk mencari perbedaan analisis menggunakan uji t-test sampel independen (independent t-tes) pada nilai karakter sikap hormat diperoleh bahwa $\mathrm{H}_{0}$ ditolak sebab sig $=0,000<0,05=a$, sehingga dapat disimpulkan bahwa ada perbedaan yang bermakna dari rata-rata hasil nilai karakter sikap hormat dari ketiga sampel tersebut. Selanjutnya, hasil yang diperoleh pada nilai karakter tanggung jawab $\mathrm{H}_{0}$ ditolak sebab sig $=0,000<0,05=a$, sehingga dapat disimpulkan bahwa ada perbedaan yang bermakna dari rata-rata hasil nilai karakter tanggung jawab dari ketiga sampel tersebut. Kesimpulan analisis tersebut dapat dipaparkan lebih lanjut sebagai berikut.

\section{Perbandingan H asil O bservasi Karakter Si- kap H ormatdan Tanggung Jawab pada Ke- las Eksperimen dan Kelas Kontrol \\ Hasil observasi sikap hormat pada kelas eksperimen 1 , eksperimen 2 dengan kelas kontrol dapat dilihat pada Tabel 5.}


Tabl 5. Hasil O bservasi Sikap Hormat

\begin{tabular}{ccccc}
\hline \multirow{2}{*}{ Perlakuan } & \multicolumn{2}{c}{ Nilai rata-rata } & \multicolumn{2}{c}{ Hasil } \\
& \multicolumn{2}{c}{ Observasi } & \multicolumn{2}{c}{ Peningkatan } \\
\cline { 2 - 5 } & Awal & Akhir & Sebesar & Persen \\
\hline $\begin{array}{c}\text { Eksperi- } \\
\text { men 1 }\end{array}$ & 56,20 & 61,80 & 5,60 & $9,96 \%$ \\
$\begin{array}{c}\text { Eksperi- } \\
\text { men 2 }\end{array}$ & 53,78 & 60,44 & 6,66 & $12,38 \%$ \\
Kontrol & 47,30 & 47,60 & 0,30 & $0,63 \%$ \\
\hline
\end{tabular}

Pada Tabel 5 terlihat bahwa terdapat peningkatan nilai rata-rata observasi sikap hormat pada kelas eksperimen 1 sebesar 5,60 atau 9,96\% dan eksperimen 2 sebesar 6,66 atau $12,38 \%$ lebih tinggi dibandingkan dengan peningkatan nilai rata-rata observasi sikap hormat pada siswa kontrol yang hanya sebesar 0,30 atau $0,63 \%$. Untuk lebih jelasnya tentang hal tersebut dapat dilihat pada Gambar 6.

Hasil observasi tanggung jawab pada kelas eksperimen 1, eksperimen 2 dan kelas kontrol dapat dilihat pada Tabel 6.

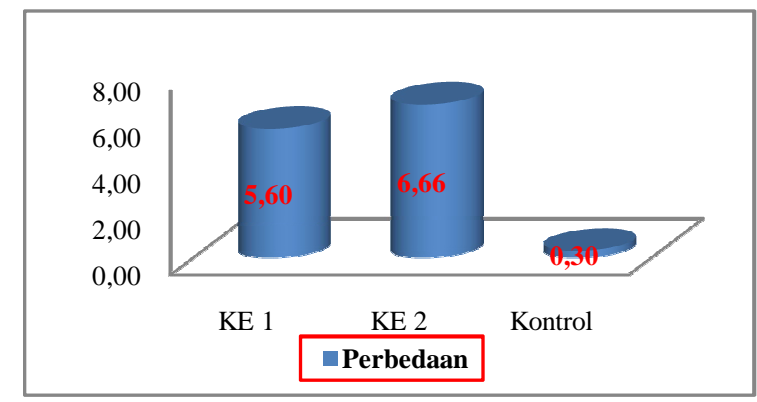

G ambar 6. Histogram H asil Perbandingan Sikap Hormat pada KE1 dan KE2 dengan Kelas kontrol

Tabel 6. Observasi Tanggung Jawab

\begin{tabular}{lcccc}
\hline \multirow{2}{*}{ Perlakuan } & \multicolumn{2}{c}{ Nilai rata-rata } & \multicolumn{2}{c}{ Hasil } \\
& \multicolumn{2}{c}{ Observasi } & \multicolumn{2}{c}{ Peningkatan } \\
\cline { 2 - 5 } & Awal & Akhir & Sebesar & Persen \\
\hline $\begin{array}{l}\text { Eksperi- } \\
\text { men 1 }\end{array}$ & 47,00 & 51,90 & 4,90 & $10,43 \%$ \\
$\begin{array}{l}\text { Eksperi- } \\
\text { men 2 }\end{array}$ & 46,78 & 51,22 & 4,44 & $9,49 \%$ \\
Kontrol & 42,50 & 43,10 & 0,60 & $1,41 \%$ \\
\hline
\end{tabular}

Berdasarkan Tabel 6 terlihat bahwa terdapat peningkatan nilai rata-rata observasi tanggung jawab pada siswa eksperimen 1 sebesar 4,90 atau 10,43\% dan eksperimen 2 sebesar 4,44 atau 9,49\% lebih tinggi dibandingkan dengan peningkatan nilai rata-rata observasi tanggung jawab pada siswa kontrol yang hanya sebesar 0,60 atau $1,41 \%$. Untuk lebih jelas tentang hal tersebut dapat dilihat pada Gambar 7.

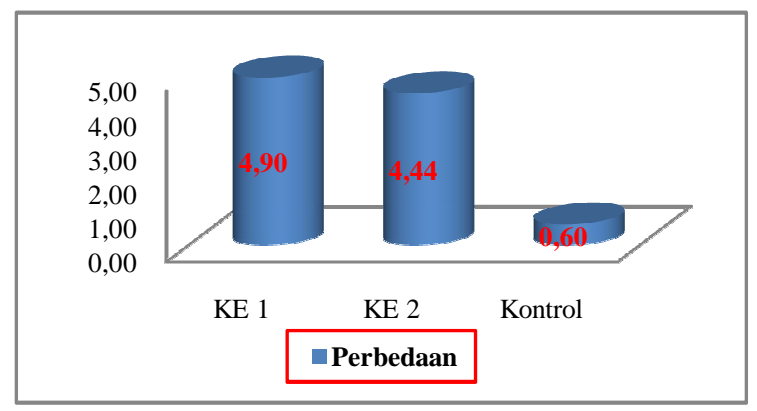

\section{G ambar 7. Histogram Hasil \\ Perbandingan Tanggung Jawab pada KE1 dan KE2 dengan Kelas kontrol}

Hasil O bservasi Sikap Hormat dan Tanggung Jawab pada Eksperimen 1 dan 2

Untuk mengetahui adanya pengaruh SSP tematik terhadap peningkatan karakter Sikap Hormat peserta didik, dilakukan dengan membandingkan hasil rata-rata observasi awal dan observasi akhir pada karakter sikap hormat yang diperoleh antara ketiga kelompok sampel. Hasil observasi karakter sikap hormat dapat disajikan ke dalam bentuk poligon pada Gambar 8 .

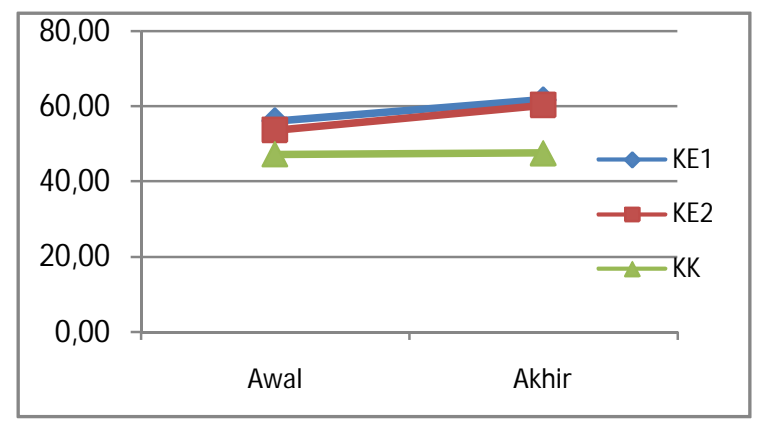

G ambar 8. Poligon Peningkatan H asil Karakter Sikap H ormat 
Hasil analisisobservasi awal sikap hormat pada siswa kelas III di SD Negeri 007 Pangkalan Kerinci Kabupaten Pelalawan menunjukan bahwa pada kelas eksperimen satu (KE1) dengan nilai rata-rata 56,20 , nilai tertinggi 60,00 , nilai terendah 54,00 , dan standar deviasi 1,68655. Pada kelas eksperimen dua (KE2) nilai rata-rata 53,78 , nilai tertinggi 56,00 , nilai terendah 50,00 , dan standar deviasi 2,10819. Pada kelas kontrol (KK), nilai rata-rata 47,30, nilai tertinggi 54,00 nilai terendah 38,00 , dan standar deviasi 4,47338. Selanjutnya, hasil analisis observasi akhir sikap hormat pada siswa kelas III di SD Negeri 007 Pangkalan Kerinci Kabupaten Pelalawan pada kelas eksperimen satu (KE1) nilai rata-rata 61,80 , nilai tertinggi 65,00 , nilai terendah 60,00 , dan standar deviasi 1,81353. Pada kelas eksperimen dua (KE2) nilai rata-rata 60,44 , nilai tertinggi 64,00 , nilai terendah 56,00 , dan standar deviasi 2,50555. Pada kelas kontrol (KK) nilai rata-rata 47,60 , nilai tertinggi 53,00 , nilai terendah 40,00 , dan standar deviasi 3,86437.

Untuk mengetahui adanya pengaruh SSP tematik terhadap peningkatan karakter tanggung jawab peserta didik, diketahui dengan membandingkan hasil rata-rata observasi awal dan observasi akhir pada karakter tanggung jawab yang diperoleh antara ketiga kelompok sampel. Hasil observasi karakter sikap hormat dapat disajikan kedalam bentuk poligon pada Gambar 9.

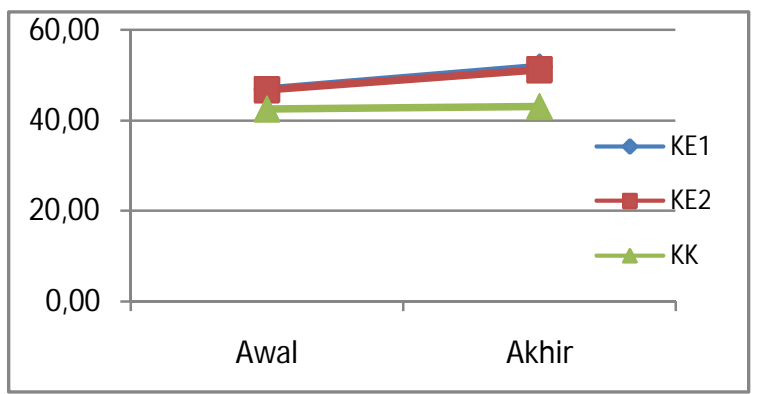

G ambar 9. Poligon Peningkatan Hasil O bservasi Karakter Tanggung Jawab
Hasil analisis observasi awal tanggung jawab pada siswa kelas III di SD Negeri 007 Pangkalan Kerinci Kabupaten Pelalawan menunjukan bahwa pada kelas eksperimen satu (KE1) dengan nilai ratarata 47,00 , nilai tertinggi 53,00 , nilai terendah 44,00, danstandar deviasi 2,53859. Pada kelas eksperimen (KE2) dengan nilai ratarata 46,78 , nilai tertinggi 52,00 , nilai terendah 39,00, dan standar deviasi 3,76755. Pada kelas kontrol (KK) nilai rata-rata sebesar 42,50 nilai tertinggi 47,00 , nilai terendah 37,00, dan standar deviasi 3,24037. Selanjutnya, hasil analisis observasi akhir tanggung jawab pada siswa kelas III di SD Negeri 007 Pangkalan Kerinci Kabupaten Pelalawan pada kelas eksperimen satu (KE1) dengan nilai rata-rata 51,90 , nilai tertinggi 56,00 , nilai terendah 49,00, dan standar deviasi 1,91195. Pada kelas eksperimen (KE2) nilai rata-rata sebesar 51,22 , nilai tertinggi 55,00 , nilai terendah 45,00 , dan standar deviasi 3,15348. Pada kelas kontrol (KK) nilai rata-rata sebesar 43,10 , nilai tertinggi 47,00 , nilai terendah 39,00 , dan standar deviasi 3,86437.

Hasil observasi sikap hormat dan tanggung jawab pada siswa kelas III di SD Negeri 007 Pangkalan Kerinci Kabupaten Pelalawan di atas termasuk pada kategori baik. Hal tersebut perlu lebih ditingkatkan melalui perangkat pembelajaran yang mendidik, tersusun dan terarah dengan tujuan agar siswa dapat memiliki sikap yang baik. Pada dasarnya sikap yang baik merupakan salah satu tujuan pendidikkan yang diwujudkan dalam pembelajaran.

\section{Pengaruh SSP Tematik terhadap Karakter Sikap Hormat dan Tanggung Jawab}

Hasil analisis menunjukkan bahwa SSP tematik berpengaruh terhadap peningkatan karakter sikap hormat dan tanggung jawab. Terdapat pengaruh dari besarnya 
peningkatan hasil observasi sikap hormat dan tanggung jawab setelah diberi perlakuan dengan menggunakan SSP tematik dalam proses pembelajaran. Pengaruh tersebut dapat dilihat dari nilai rata-rata sebelum dan sesudah diberi perlakuan, yaitu nilai rata-rata sikap hormat siswa sebelum diberikan perlakuan pada ekperimen $1 \mathrm{se}$ besar 56,20 dan setelah diberi perlakuan SSP tematik nilai rata-rata siswa sebesar 61,80. Pada ekperimen 2 sebesar 53,78 dan setelah diberi perlakuan SSP tematik nilai rata-rata meningkat menjadi 60,44 . Hal ini berarti SSP tematik dapat berpengaruh terhadap sikap hormat siswa pada eksperimen 1 sebesar 5,60 atau 9,96\% dan pengaruh pada eksperimen 2 sebesar 6,66 atau $12,38 \%$. Nilai rata-rata tanggung jawab siswa sebelum diberikan perlakuan pada eksperimen 1 sebesar 47,00 dan setelah diberi perlakuan SSP tematik menjadi 51,90. Pada eksperimen 2 sebesar 46,78 dan setelah diberi perlakuan SSP tematik menjadi 51,22. $\mathrm{H}$ al tersebut berarti SSP tematik dapat berpengaruh terhadap tanggung jawab siswa padaeksperimen 1 sebesar 4,90 atau 10,43\% dan pengaruh pada eksperimen 2 sebesar 4,44 atau 9,49\%. Hasil tersebut menunjukkan bahwa menggunakan SSP tematik dapatberpengaruh terhadapsikap hormat dan tanggung jawab siswa. Uraian-uraian di atas juga menunjukkan bahwa SSP tematik baik digunakan dalam meningkatkan karakter sikap hormat dan tanggung jawab sehingga siswa lebih memiliki akhlak yang baik dalam proses pembelajaran dan dapat diwujudkan dalam kehidupan sehari-hari.

\section{Sikap Hormat dan Tanggung Jawab an- tara Siswa yang Diberi Perlakuan dengan Siswa yang Tidak D iberi Perlakuan}

Berdasarkan hasil analisis sebagaimana telah dijelaskan di atas, terdapat perbedaan nilai rata-rata antara siswa yang di- beri perlakuan dengan menggunakan SSP tematik dengan siswa yang tidak menggunakan SSP tematik dalam pembelajaran. $\mathrm{Hal}$ ini dapat dilihat dari nilai rata-rata siswa yang diberi perlakuan SSP tematik dalam proses pembelajaran terhadap sikap hormat, yaitu sebesar 61,80 pada eksperimen 1 dan 60,44 pada eksperimen 2, sedangkan pada siswa yang tidak menggunakan SSP tematik dalam proses pembelajaran terhadap sikap hormat hanya sebesar 47,60 .

Nilai rata-rata siswa yang diberi perlakuan SSP tematik dalam proses pembelajaran terhadap karakter tanggung jawab sebesar 51,90 pada eksperimen 1 dan 51,22 pada siswa eksperimen 2, sedangkan pada siswa yang tidak menggunakan SSP tematik hanya sebesar 43,10. Hasil tersebut menunjukkan bahwa nilai rata-rata siswa yang diberi perlakuan SSP tematik lebih tinggi dibandingkan dengan nilai rata-rata siswa yang tidak diberi perlakuan SSP tematik. $\mathrm{Hal}$ tersebut sesuai dengan teori Shulman (1986:9) yang menjelaskan, "P edagogical Content Knowledge (PCK) dalam pembelajaran sebagai berikut. Pedagogical Content Knowledge includes "the most useful forms of representation of topics, the most powerful analogies, illustrations, examples, explanations, and demonstrations in a word, the ways of representing and formulating the subject that make it comprehensible to others. Pedagogical content knowledge also includes an understanding of what makes the learning of specific topics easy or difficult: the conceptions and preconceptions that students of different ages and backgrounds bring with them to the learning of those most frequently taught topics and lessons". Maksudnya, PCK termasuk bentuk representasi topikyang paling berguna, analogi yang paling kuat dalam ilustrasi, contoh, penjelasan, dan demonstrasi. Cara ini mewakili bagi guru untuk merumuskan topik yang dapat dipahami siswa. PCK juga mencakup pe- 
mahaman tentang hal-hal yang membuat pembelajaran pada topik tertentu mudah atau sulit dipahami siswa dengan konsepsi dan prasangka bahwa siswa dari berbagai usia dan latar belakang yang berbeda. PCK dapat membawa mereka ke pembelajaran satu topik yang paling sering diajarkan. Baker (2006:2) menyatakan, "Subject Specific Pedagogy represents current efforts to integrate the learning of content with the learning of pedagogy-a goal that has attracted and eluded teacher educators for more a century". M aksud kutipan tersebut adalah bahwa SSP merupakan upaya untuk mengintegrasikan isi pembelajaran dengan belajar yang mendidik dan tujuan pembelajaran yang menarik dengan dinyatakan sebagai produk yang ditampilkan dalam bentuk perangkat pembelajaran yang mendidik dan komprehensifyang mencakup standar kompetensi, materi, strategi, metode, media serta evaluasi. Perangkat pembelajaran yang diperlukan untuk mengembangkan kompetensi meliputi komponen silabus, RPP, media pembelajaran, materi ajar, lembar kerja siswa, dan instrumen hasil berlajar.

\section{PEN UTUP}

\section{Simpulan}

Berdasarkan hasil penelitian dan hasil analisis data yang telah dilakukan, dapat disimpulkan bahwa terdapat pengaruh SSP tematik yang signifikan terhadap karakter sikap hormat dan tanggung jawab pada siswa kelas III SD Negeri 007 Pangkalan Kerinci Kabupaten Pelalawan. Pengaruh tersebut dapat dijelaskan sebagai berikut. Pertama, pengaruh SSP tematik terhadap karakter sikap hormat signifikan. Ke dua, pengaruh SSP tematik terhadap karakter tanggung jawab signifikan.

Signifikansi ini dicapai dengan caracara sebagai berikut. Pertama, Pembelajaran menggunakan SSP tematik pada siswa eksperimen 1 dan 2 , untuk 1 tema pelajaran selama 3 minggu atau 18 hari. Kedua, perubahan karakter sikap hormat dan tanggung jawab siswa diamati (observasi) setiap hari yaitu selama 18 hari. Ketiga, untuk mengetahui perubahan karakter tersebut dengan membandingkan hasil observasi awal dengan observasi akhir. Hasil observasi akhir diperoleh dari jumlah nilai observasi setiap hari kemudian diambil rata-ratanya. Selanjutnya, dilakukan analisis dengan menggunakan uji perpasangan (paired t- tes). Keempat, perubahan nilai rata-rata observasi karakter sikap hormat sebesar 5,60 atau $9,96 \%$ pada eksperimen 1 , sedangkan pada eksperimen 2 sebesar 6,66 atau $12,38 \%$. Kelima, perubahan nilai ratarata observasi karakter tanggung jawab se besar 4,90 atau 10,49\% pada eksperimen 1, sedangkan pada eksperimen 2 sebesar 4,44 atau $9,49 \%$.

Perbedaan pengaruh dari karakter sikap hormat dan tanggung jawab adalah sebagai berikut. Pertama, perbedaan karakter sikap hormat antara siswa yang mengikuti pembelajaran menggunakan SSP tematik dan pembelajaran tidak menggunakan SSP tematik signifikan. Kedua, perbedaan karakter tanggung jawab antara siswa yang mengikuti pembelajaran menggunakan SSP tematik dan pembelajaran tidak menggunakan SSP tematik signifikan.

Signifikansi ini diperoleh dengan caracara sebagai berikut. Pertama, membandingkan perubahan nilai karakter sikap hormat dan tanggung jawab siswa yang diamati pada masing-masing selama 3 minggu atau 18 hari. Selanjutnya dianalisis dengan menggunakan uji beda Independen $T$ tes. Kedua, perubahan nilai rata-rata observasi sikap hormat pada eksperimen 1 sebesar 5,60 atau 9,96\% dan sebesar 6,66 atau $12,38 \%$ pada eksperimen 2 , sedangkan kontrol hanya sebesar 0,30 atau 0,63\%. Ketiga, 
perubahan nilai rata-rata observasi tanggung jawab pada eksperimen 1 sebesar 4,90 atau $10,43 \%$ dan sebesar 4,44 atau 9,49\% pada eksperimen 2 , sedangkan kontrol hanya sebesar 0,60 atau $1,41 \%$.

\section{Saran}

Berdasarkanhasil penelitian maka kepada para guru atau tenaga pengajar di se kolah, diberikan saran-saran sebagai berikut. Pertama, pembelajaran yang baik akan terwujud dengan perencanaan yang baik pula, salah satu perencanaan yang telah teruji adalah perangkat pembelajaran yang mendidik berupa SSP tematik. Kedua, SSP tematik memiliki pengaruh yang lebih baik terhadap katakter sikap hormat dan tanggung jawab sehingga para guru atau tenaga pendidik sebaiknya memilih perangkat pembelajaran yang tersusun dalam SSP tematik. Ketiga, upaya meningkatkan karakter sikap hormat dan tanggung jawab akan lebih tepat dan efektif dengan menggunakan perangkatpembelajaran yang mendidik berupa SSP tematik.

\section{UCAPAN TERIMA KASIH}

Penulis mengucapkan terima kasih kepada Kaprodi Pendidikan Dasar Program Pascasarjana Universitas Negeri Yogyakarta yang banyak membantu dan memberi motivasi demi lancaranya penelitian ini. Terima kasih juga diucapkan kepada $\mathrm{Re}$ daktur Jurnal Pendidikan Karakter yang telah menelaah dan memberi masukan demi kelayakan tulisan.

\section{DAFTAR PUSTAKA}

Baker, M. \& Chick, H. 2006. Pedagogical Content Knowledge for Teaching Primary M athematics: A Case Study of Two Teachers. A ustralian Research Council grant DP0344229.
California State University Northridge. 2006. Effective teaching. Teachers for a $\mathrm{N}$ ew Era. [Online]. Available: http:/ / www.csun.edu/ tne/ effective\%20teac hing\%20jan\%2006\%20FIN A L.pdf

Clemes, H. \& Bean, R. 2001. M elatih Anak Bertanggung Jawab. (Terjemahan Anton Adiwijoyo). Jakarta: Mitra Utama.

Lickona, T. 1991. Educating for Character: How Our Schools Can Teach Respect and Responsibility. N ew York: Bantam Books.

McMillan, J.H., \& Schumacher, S. 2010. Research in Education: Evidence-based inquiry. $7^{\text {th }}$ ed. New York: Person Education. Inc.

Peraturan M enteri Pendidikan N asional N omor 22 Tahun 2006 tentang Standar Isi untuk Satuan Pendidikan Dasar dan Menengah.

Peratuan Pemerintah Nomor 19 Tahun 2005 tentang Standar Nasional Pendidikan.

Rich, D. 2008. M egaskills: Building our Children's Character and Achievment for School and Life. Naperville, Illinois: Sourcebooks, Inc.

Shulman, L. S. 1986. “Those Who Understand: Knowledge Growth in Teaching". Educational Researcher, Vol.15, No. 2, pp 4-14. 